\title{
Different combined oral contraceptives and the risk of venous thrombosis: systematic review and network meta-analysis
}

\author{
(c) $\frac{(1)(8)}{\text { ay }}$ OPEN ACCESS
}

\author{
Bernardine H Stegeman research associate ${ }^{13}$, Marcos de Bastos research fellow ${ }^{2}$, Frits R Rosendaal \\ professor of clinical epidemiology ${ }^{3}$, A van Hylckama Vlieg research fellow ${ }^{4}$, Frans M Helmerhorst \\ professor of clinical epidemiology of fertility ${ }^{25}$, Theo Stijnen professor of medical statistics ${ }^{6}$, Olaf $\mathrm{M}$ \\ Dekkers research fellow ${ }^{7}$
}

\begin{abstract}
${ }^{1}$ Department of Epidemiology and Public Health, University College London, London, UK; ${ }^{2}$ Department of Clinical Epidemiology, Leiden University Medical Center, Leiden, Netherlands; ${ }^{3}$ Department of Clinical Epidemiology, Department of Thrombosis and Haemostasis, Einthoven Laboratory for Experimental Vascular Medicine, Leiden University Medical Center, Netherlands; ${ }^{4}$ Department of Clinical Epidemiology, Einthoven Laboratory for Experimental Vascular Medicine, Leiden University Medical Center, Netherlands ; ${ }^{5}$ Department of Gynaecology and Reproductive Medicine, Leiden University Medical Center, Netherlands; ${ }^{6}$ Department of Medical Statistics, Leiden University Medical Center, Netherlands; ${ }^{7}$ Department of Clinical Epidemiology, Department of Endocrinology and Metabolism, Leiden University Medical Center, 2333 ZA Leiden, Netherlands
\end{abstract}

\begin{abstract}
Objective To provide a comprehensive overview of the risk of venous thrombosis in women using different combined oral contraceptives.

Design Systematic review and network meta-analysis.

Data sources PubMed, Embase, Web of Science, Cochrane, Cumulative Index to Nursing and Allied Health Literature, Academic Search Premier, and ScienceDirect up to 22 April 2013.

Review methods Observational studies that assessed the effect of combined oral contraceptives on venous thrombosis in healthy women. The primary outcome of interest was a fatal or non-fatal first event of venous thrombosis with the main focus on deep venous thrombosis or pulmonary embolism. Publications with at least 10 events in total were eligible. The network meta-analysis was performed using an extension of frequentist random effects models for mixed multiple treatment comparisons. Unadjusted relative risks with $95 \%$ confidence intervals were reported. The requirement for crude numbers did not allow adjustment for potential confounding variables.

Results 3110 publications were retrieved through a search strategy; 25 publications reporting on 26 studies were included. Incidence of venous thrombosis in non-users from two included cohorts was 1.9 and 3.7 per 10000 woman years, in line with previously reported incidences of 1-6 per 10000 woman years. Use of combined oral contraceptives increased the risk of venous thrombosis compared with non-use (relative risk 3.5, $95 \%$ confidence interval 2.9 to 4.3 ). The relative risk of venous
\end{abstract}

thrombosis for combined oral contraceptives with 30-35 $\mu \mathrm{g}$ ethinylestradiol and gestodene, desogestrel, cyproterone acetate, or drospirenone were similar and about $50-80 \%$ higher than for combined oral contraceptives with levonorgestrel. A dose related effect of ethinylestradiol was observed for gestodene, desogestrel, and levonorgestrel, with higher doses being associated with higher thrombosis risk.

Conclusion All combined oral contraceptives investigated in this analysis were associated with an increased risk of venous thrombosis. The effect size depended both on the progestogen used and the dose of ethinylestradiol.

\section{Introduction}

Shortly after the introduction of the first combined oral contraceptive (containing an oestrogen and a progestogen), a case of venous thrombosis associated with contraceptive use was reported. ${ }^{1}$ Since then, many observational studies have shown that combined oral contraceptives are associated with a twofold to sixfold increased risk of venous thrombosis. ${ }^{2.5}$ Despite the low incidence of venous thrombosis-about three per 10 000 woman years - among women of reproductive age, ${ }^{6}$ the effect of combined oral contraceptives on venous thrombosis is large, owing to the fact that many women use oral contraceptives. 
Because the oestrogen compound (ethinylestradiol) in combined oral contraceptives was thought to cause the increased risk in thrombosis, the dose of ethinylestradiol was lowered from $150-100 \mu \mathrm{g}$ in the earliest brands to $50 \mu \mathrm{g}$ in the $1960 \mathrm{~s}$, and to $30-35 \mu \mathrm{g}$ and $20 \mu \mathrm{g}$ in the $1970 \mathrm{~s} .^{7-9}$ The reduced dose of ethinylestradiol in contraceptives was indeed associated with a reduction in the risk of venous thrombosis. ${ }^{10-14}$ Apart from adjustments in the dose of ethinylestradiol, the progestogen compound was also changed in an effort to reduce side effects. After the first generation progestogens (that is, norethisterone and lynestrol), new progestogens were developed. These new compounds were called second generation (that is, levonorgestrel) and third generation progestogens (that is, gestodene, desogestrel, norgestimate).${ }^{15}$ However, users of combined oral contraceptives with third generation progestogens have a higher risk of venous thrombosis than those using second generation progestogens. ${ }^{16-19}$ Other progestogens have been developed after the introduction of third generation progestogens - that is, drospirenone (introduced in 2001). The thrombosis risk for contraceptives with drospirenone was found to be higher than for combined oral contraceptives with second generation progestogens. ${ }^{20} 21$

The present network meta-analysis aimed to provide an overview of the risk of venous thrombosis per combined oral contraceptive in healthy women, and assess the effect of the generation of progestogen used. We performed a network meta-analysis because combined oral contraceptives are mostly compared with non-use or with a contraceptive containing levonorgestrel with $30 \mu$ g ethinylestradiol. These comparisons resulted in gaps in direct evidence, because not every combined oral contraceptive was directly compared with other possible combined oral contraceptives. A network meta-analysis allows evidence from direct and indirect comparisons to be summarised in a weighted average for all possible comparisons.

\section{Methods}

\section{Search strategy and selection criteria}

Publications of interest were observational studies (cohort or (nested) case-control studies) that included healthy women using combined oral contraceptives. The primary outcome of interest was a fatal or non-fatal first event of venous thrombosis with the main focus on deep venous thrombosis or pulmonary embolism. Publications with a minimum of 10 events in total were eligible.

The following databases were searched: PubMed (984 articles retrieved), Embase (1339), Web of Science (306), Cochrane (57), Cumulative Index to Nursing and Allied Health Literature (122), Academic Search Premier (197), and ScienceDirect (105). Our search terms consisted of MeSH headings and subheadings, text words, and word variations for "combined oral contraceptive," "estrogens," "progestogens," and "venous thromboembolism." This search strategy was amended for each database. We searched each database from inception until 22 April 2013 (date of final search). No language restriction was applied. In addition to database searches, we checked references of potential interesting publications.

A standard form was used to select publications. Two investigators (BHS, MdB) independently assessed publications for eligibility. Titles and abstracts were screened and if deemed potentially relevant, full text articles were retrieved. Any disagreements between the investigators were discussed and if necessary, a third reviewer (OMD) was asked to resolve disagreements. In case of multiple publications from the same study, the publication with the most updated or the most inclusive data was included. Web appendix 1 shows details of the search strategy.

\section{Data collection}

Two investigators (BHS and MdB) independently extracted data using a standard form. Data were extracted on type of combined oral contraceptive (dose and type of oestrogen and progestogen), crude numbers for exposure and outcome, crude and adjusted risk estimates, and variables adjusted for in the analysis. In case of incomplete data for dose or type of oestrogen or progestogen, authors were approached for extra information. In total, 10 authors were sent an email on 25 July 2012 and if necessary, a reminder on 20 August 2012. Of these authors, $80 \%$ replied to our emails. If provided, data for the absolute thrombosis risk in non-users were extracted from the cohort studies. For sensitivity analyses, data for the funding source and first time use were abstracted.

Risk of bias assessment was based on design features that could potentially bias the association between exposure and outcome. We assessed adequacy of exposure (oral contraceptive) and outcome (venous thrombosis) measurement, loss to follow-up (cohort studies), and adequacy of control selection (case-control studies). Women are more likely to remember that they used oral contraceptives than what specific preparation they used..$^{223}$ Therefore, assessment of the type of combined oral contraceptive through an interview or questionnaire was classified as high risk of bias, and information from a prescription database as low risk. Only $25-33 \%$ of patients presenting with clinical symptoms suggestive of venous thrombosis are objectively diagnosed with venous thrombosis. ${ }^{24}$ Therefore, studies with objective confirmation in all patients were judged as low risk of bias. Venous thrombosis was considered objectively confirmed when a deep venous thrombosis was diagnosed by plethysmography, ultrasound examination, computed tomography, or venography; or when pulmonary embolism was diagnosed by ventilation-perfusion scanning, spiral computed tomography, or pulmonary angiography. ${ }^{25}{ }^{26}$ Less than $10 \%$ loss to follow-up was considered to represent a low risk of bias. For case-control studies, controls selected from hospital populations was considered to confer a high risk of bias. ${ }^{27}$

\section{Classification of type of combined oral contraceptive}

There is no generally accepted way to classify combined oral contraceptives according to generations of progestogens. In this analysis, the most common classification system was used, which is in line with biological properties per group and is reflected in their effects on levels of sex hormone binding globulin. ${ }^{28}{ }^{29}$ For the aim of the present network meta-analysis per generation of progestogen, the following progestogens were classified as first generation; lynestrenol and norethisterone. Norgestrel and levonorgestrel were categorised as second generation progestogens; and desogestrel, gestodene, and norgestimate were classified as third generation progestogens. ${ }^{15}$ This classification was irrespective of ethinylestradiol dose. Publications reporting on generations according to another classification were included. To assess the influence of combining different classifications, we performed an analysis restricted to studies using the above described classification.

Many different combined oral contraceptives are available. We selected 10 frequently prescribed oral contraceptives for the network meta-analysis:

- $20 \mu$ g ethinylestradiol with levonorgestrel (20LNG)

- $30 \mu \mathrm{g}$ ethinylestradiol with levonorgestrel (30LNG) 
- $50 \mu$ g ethinylestradiol with levonorgestrel (50LNG)

- $20 \mu \mathrm{g}$ ethinylestradiol with gestodene (20GSD)

- $30 \mu \mathrm{g}$ ethinylestradiol with gestodene (30GSD)

- $20 \mu \mathrm{g}$ ethinylestradiol with desogestrel (20DSG)

- $30 \mu \mathrm{g}$ ethinylestradiol with desogestrel (30DSG)

- $35 \mu$ g ethinylestradiol with norgestimate (35NRG)

- $35 \mu \mathrm{g}$ ethinylestradiol with cyproterone acetate (35CPA)

- $30 \mu \mathrm{g}$ ethinylestradiol with drospirenone (30DRSP)

We categorised 20LNG, 30LNG, and 50LNG as second generation progestogens, and 20GSD, 30GSD, 20DSG, 30DSG, and 35NRG as third generation progestogens. 35CPA and 30DRSP were not used in this classification by generations.

\section{Statistical analysis}

A network meta-analysis was conducted per generation of progestogen in a combined oral contraceptive and per selected oral contraceptive preparation. We used an extension of frequentist random effects models for mixed multiple treatment comparisons. The network meta-analysis was performed with the mvmeta command for Stata, as described by White and colleagues. ${ }^{30}$ We used crude data from a $2 \times 2$ table in the analysis. Odds ratios, risk ratios, or rate ratios and appropriate variances were computed and combined in the analysis leading to an overall relative risk. For publications with zero events in one cell of a $2 \times 2$ table, all cells of that $2 \times 2$ table were inflated by adding 0.5 . If more than one study provided data for the same stratum (that is, data for generations of progestogen or on specific contraceptive preparations), we checked consistency of the results. An interaction term was added to the model to estimate the difference in results from direct and indirect evidence. All potential interactions were tested in an overall test to determine whether there were any inconsistencies in our network meta-analysis.

The following sensitivity analyses were planned: per study design, per funding source (whether industry sponsored or not), within first time users, and according to risk of bias. All statistical analyses were performed with Stata, version 12.0 (Statacorp LP).

\section{Results}

\section{Characteristics of included studies}

Of 3110 publications retrieved through electronic and references searches, 2144 were excluded after screening the title and abstract and 81 were excluded after detailed assessment of the full text (fig $1 \Downarrow$; web table 1 provides reasons for exclusion). Overall, 26 studies reported in 25 articles were included (one article ${ }^{10}$ presented two studies). Two publications provided important additional information to studies included in the meta-analysis (information on first time use); data from these publications were added to the respective studies already included. Table $1 \Downarrow$ shows details of included studies. Nine cohort studies, three nested case-control studies, and 14 case-control studies were included.

Two studies reported the absolute risk of venous thrombosis in non-users: 1.9 and 3.7 per 10000 woman years. Based on data from 15 studies that included a non-user group, use of combined oral contraceptives was found to increase the risk of venous thrombosis fourfold (relative risk 3.5, 95\% confidence interval 2.9 to 4.3$)$.

\section{Risk of bias}

Eight studies assessed combined oral contraceptive use through an interview or questionnaire (web table 2). Only five studies objectively confirmed venous thrombosis in all patients, whereas 14 studies objectively confirmed venous thrombosis in a proportion of the population or subjectively confirmed venous thrombosis. Five case-control studies selected controls from a population in hospital care. Of the nine cohort studies, none provided information about loss to follow-up.

\section{Network meta-analysis comparing generations of progestogens}

A total of 23 studies were included for the analysis stratified per generation of progestogen. Three studies reported solely on the risk of venous thrombosis in drospirenone, which is not classified as a generation of progestogen. Web table 3 provides details of the number of events and total number of women or total follow-up time per generation, and web table 4 provides the study specific adjusted risk estimates.

Table $2 \Downarrow$ shows results of the network meta-analysis according to generations of progestogen. Compared with non-users, the risk of venous thrombosis in users of oral contraceptives with a first generation progestogen increased 3.2-fold (95\% confidence interval 2.0 to 5.1), 2.8-fold (2.0 to 4.1) for second generation progestogens, and 3.8-fold (2.7 to 5.4) for third generation progestogens. The risk of venous thrombosis in second generation progestogen users was similar to the risk in first generation users (relative risk $0.9,0.6$ to 1.4 ). Third generation users had a slightly higher risk than second generation users $(1.3,1.0$ to 1.8$)$. Restricted to studies with an identical classification of generations (see methods section for classification used), the results of each generation compared with non-use remained the same (first generation relative risk $3.2,95 \%$ confidence interval 1.6 to 6.4 ; second generation 2.6, 1.5 to 4.7 ; third generation $3.5,2.0$ to 6.1$)$. A formal interaction test did not show inconsistencies in the network $\left(\chi^{2}=2.97\right.$, $\mathrm{P}=0.71$ ).

\section{Network meta-analysis comparing different combined oral contraceptives}

Of 14 studies providing data per type of oral contraceptive (web tables 5 and 6), at least one preparation was compared with non-use or two types were compared directly. Table $3 \Downarrow$ shows results of the analysis. All preparations were associated with a more than twofold increased risk of venous thrombosis compared with non-use (fig $2 \Downarrow$ ). The relative risk estimate was highest in 50LNG users and lowest in 20LNG and 20GSD users. A dose related effect was observed for gestodene, desogestrel, and levonorgestrel, with higher doses being associated with higher thrombosis risk. The risk of venous thrombosis for 35CPA and 30DRSP was similar to the risk for 30DSG (relative risk $0.9,95 \%$ confidence interval 0.6 to 1.3 and $0.9,0.7$ to 1.3 , respectively, compared with $30 \mathrm{DSG}$ ). A formal interaction test could not be performed because only two of 14 studies provided data for exactly the same contraceptives.

\section{Sensitivity analyses}

We performed sensitivity analyses according to funding source, study design, and method of diagnosis confirmation (objective $v$ subjective confirmation of venous thrombosis). Table $4 \Downarrow$ shows sensitivity analyses performed according to generation of progestogen. Results from the sensitivity analysis stratified by funding source showed that the risk estimate for third generation users (compared with non-users) was lower in industry 
sponsored studies than in non-industry sponsored studies (relative risk $1.9 v 5.2$ ). In cohort studies, the risk estimate for third generation users (compared with non-users) was lower than the risk for third generation users in case-control studies $(2.0 v 4.2)$. All risk estimates were higher in studies with objectively confirmed venous thrombosis, of which none were industry sponsored.

\section{Discussion}

We performed a network meta-analysis based on 26 studies. Overall, combined oral contraceptive use increased the risk of venous thrombosis fourfold. The reported incidence of venous thrombosis in non-users was in line with the literature. We observed that all generations of progestogens were associated with an increased risk of venous thrombosis and that third generation users had a slight increased risk compared with second generation users. All individual types of combined oral contraceptives increased thrombosis risk compared with non-use more than two-fold. The highest risk of venous thrombosis was found among 50LNG users, and the risk was similar in 30DRSP, 35CPA, and 30DSG users. Users of 30LNG, 20LNG, and 20GSD had the lowest thrombosis risk.

\section{Strengths and limitations}

A network meta-analysis summarises data from direct and indirect comparisons in a weighted average. In the present study, this resulted in a comprehensive overview of the risk of venous thrombosis in frequently prescribed combined oral contraceptives. The internal validity of the network meta-analysis was assessed through interaction analysis modelling potential inconsistencies in the network. ${ }^{30}$ Our results of the analysis based on generations of progestogens indicated that potential inconsistencies are likely the result of chance.

A limitation of our network meta-analysis was that publications had to provide the crude number of users and number of events per type of combined oral contraceptive. A total of 15 studies provided information on combined oral contraceptive use and thrombosis risk without specification of which contraceptive preparations were used. These studies could therefore not be included. Because of the need for crude numbers in the network meta-analysis, adjusted risk estimates were not used for pooling the data. Confounding could have influenced our results. Age is a potential confounder for the association between contraceptive use and venous thrombosis. Women using second generation contraceptives are generally older than users of third generation contraceptives. If an analysis is not adjusted for age, the relative risk will then underestimate the risk of venous thrombosis in users of third generation contraceptives compared with users of second generation contraceptives. This implies that the risk of third generation users may be higher than reported here. However, age was often dealt with in the design of the studies. Body mass index is only weakly associated with combined oral contraceptive use, and analyses unadjusted for body mass index are probably not confounded.

There is no generally accepted way to classify oral contraceptives according to generations of progestogens. For instance, norgestimate can be categorised as a second or a third generation progestogen. As a consequence, the classification of these generations was not the same in every publication. However, the results did not materially change when restricted to studies with an identical classification of generations as described in the methods nor when contraceptives with desogestrel or gestodene were compared with levonorgestrel (that is, norgestimate was not taken into account when classifying contraceptives into generations) (data not shown).

In the classification of progestogen generations used in this meta-analysis, the dose of ethinylestradiol was not taken into account. The observed increased risk in third generation contraceptives, compared with second generation contraceptives, cannot be explained by a difference in ethinylestradiol dose because a higher dose of ethinylestradiol $(50 \mu \mathrm{g})$ can be present in a second generation contraceptive but not in a third generation contraceptive.

In only a few included studies, venous thrombosis was objectively confirmed in all patients. Only about $30 \%$ of patients with clinical symptoms of thrombosis are diagnosed with venous thrombosis. ${ }^{24}$ Including patients without objectively confirmed venous thrombosis would lead to overestimating the association when oral contraceptives users were more likely to be diagnosed than non-users (diagnostic suspicion bias). However, two studies showed that this bias was independent of type of oral contraceptive. ${ }^{18}{ }^{52}$ In studies without objective confirmation, women were misclassified irrespective of their contraceptive use, leading to non-differential misclassification. Therefore, results of such studies may underestimate the true association, which was confirmed by our sensitivity analysis where the risk estimates were higher in studies with objectively confirmed venous thrombosis than in those without an objective confirmation.

Two other meta-analyses ${ }^{18}{ }^{53}$ have evaluated the risk of venous thrombosis comparing third generation contraceptive users with second generation users. Both studies found an increased risk in third generation users (relative risk $1.5,95 \%$ confidence interval 1.2 to $1.8^{18} ; 1.57,1.24$ to $1.98^{53}$ ), which are in line with our results. The majority of included studies from both meta-analyses were included in our analysis.

\section{Clinical implications of the study}

Although we observed that the risk of venous thrombosis increased with the dose of ethinylestradiol, this seemed to depend on the progestogen provided. There was no difference in the venous thrombosis risk between 20LNG and 30LNG, whereas a difference in the risk was observed between 20DSG and 30DSG, for example. It is unclear why the dose effect of ethinylestradiol might depend on the progestogen. A possibility is that there is a difference in inhibitory effects of the progestogen on the procoagulant effect of ethinylestradiol. Oral contraceptive use increases the levels of factors II, VII, VIII, protein $\mathrm{C}$, and decreases the levels of antithrombin, tissue factor pathway inhibitor, and protein S. Clinical studies have showed that this effect on coagulation factors was more pronounced in desogestrel users than in levonorgestrel users, and limited to combined oral contraceptives. ${ }^{54} 55$

Combining different preparations of oral contraceptive into generations of progestogens may not be an appropriate way to present the risk of thrombosis, because the risk depends on the dose of ethinylestradiol as well as on the progestogen provided. We suggest abstaining from any classification of contraceptives, but to compare the risk of venous thrombosis per oral contraceptive preparation.

It should be kept in mind that all combined oral contraceptives increase the risk of venous thrombosis, which is not the case for the levonorgestrel intrauterine device.$^{56}$ However, if a woman prefers using combined oral contraceptives, only contraceptives with the lowest risk of venous thrombosis and good compliance should be prescribed, such as levonorgestrel with $30 \mu \mathrm{g}$ ethinylestradiol. Current practice is to increase the dose of 
ethinylestradiol in case of disruptions in bleeding patterns. ${ }^{57}$ Our results indicate that prescribing 50LNG in case of spotting during the use of $30 \mathrm{LNG}$ might carry a serious risk for venous thrombosis.

Contributors: BHS, MdB, FMH, and OMD developed the study design. BHS and MdB independently selected the publications and extracted data. BHS, TS, and OMD performed the statistical analysis. All authors interpreted the data and critically reviewed drafts of the manuscript. BHS is guarantor.

Funding: This study received no specific funding. BHS was supported by grant 40-00812-98-07-045 from the Netherlands Organization for Scientific Research. MdB was supported by grant from Capes-Nuffic, Brazil. The funding agencies had no role in the study design, implementation, or preparation of results.

Competing interests: All authors have completed the ICMJE uniform disclosure form at www.icmje.org/coi_disclosure.pdf and declare: no support from any organisation for the submitted work; BHS was supported by the Netherlands Organization for Scientific Research; MdB was supported by a grant from Capes-Nuffic, Brazil; no other relationships or activities that could appear to have influenced the submitted work.

Ethical approval: Not required.

Data sharing: No additional data available.

Jordan W. Pulmonary embolism. Lancet 1961;278:1146-7.

2 Oral contraception and thrombo-embolic disease. J R Coll Gen Pract 1967;13:267-79.

3 Inman WH, Vessey MP. Investigation of deaths from pulmonary, coronary, and cerebra thrombosis and embolism in women of child-bearing age. BMJ 1968;2:193-9.

Sartwell PE, Masi AT, Arthes FG, Greene GR, Smith HE. Thromboembolism and oral contraceptives: an epidemiologic case-control study. Am J Epidemiol 1969;90:365-80.

5 Vessey MP, Doll R. Investigation of relation between use of oral contraceptives and thromboembolic disease. A further report. BMJ 1969;2:651-7.

6 Naess IA, Christiansen SC, Romundstad P, Cannegieter SC, Rosendaal FR, Hammerstrom J. Incidence and mortality of venous thrombosis: a population-based study. J Thromb Haemost 2007;5:692-9.

7 Thorogood M, Villard-Mackintosh L. Combined oral contraceptives: risks and benefits. $B r$ Med Bull 1993;49:124-39.

8 Wharton C, Blackburn R. Lower dose pills. Population Rep 1988;16:1-31

9 Stolley PD, Tonascia JA, Tockman MS, Sartwell PE, Rutledge AH, Jacobs MP. Thrombosis with low-estrogen oral contraceptives. Am J Epidemiol 1975;102:197-208.

10 Venous thromboembolic disease and combined oral contraceptives: results of international multicentre case-control study. World Health Organization Collaborative Study of

Cardiovascular Disease and Steroid Hormone Contraception. Lancet 1995;346:1575-82.

11 Inman WH, Vessey MP, Westerholm B, Engelund A. Thromboembolic disease and the steroidal content of oral contraceptives. A report to the Committee on Safety of Drugs. BMJ 1970;2:203-9.

12 Vessey M, Mant D, Smith A, Yeates D. Oral contraceptives and venous thromboembolism: findings in a large prospective study. Br Med J (Clin Res Ed) 1986;292:526.

13 Lidegaard $\mathrm{O}$, Edstrom B, Kreiner S. Oral contraceptives and venous thromboembolism: a five-year national case-control study. Contraception 2002;65:187-96.

14 Meade TW, Greenberg G, Thompson SG. Progestogens and cardiovascular reactions associated with oral contraceptives and a comparison of the safety of 50 - and 30-microgram oestrogen preparations. BMJ 1980;280:1157-61.

15 Henzl MR, Edwards JA. Pharmacology of progestins: 17alpha-hydroxyprogesterone derivatives and progestins of the first and second generation. In: Sitruk-Ware RL, Mishell DR Jr, eds. Progestins and antiprogestins in clinical practice. Marcel Dekker, 2000:101-32.

16 Lidegaard O, Lokkegaard E, Svendsen AL, Agger C. Hormonal contraception and risk of venous thromboembolism: national follow-up study. BMJ 2009;339:b2890.

17 van Hylckama Vlieg A, Helmerhorst FM, Vandenbroucke JP, Doggen CJ, Rosendaal FR. The venous thrombotic risk of oral contraceptives, effects of oestrogen dose and progestogen type: results of the MEGA case-control study. BMJ 2009;339:b2921.

18 Kemmeren JM, Algra A, Grobbee DE. Third generation oral contraceptives and risk of venous thrombosis: meta-analysis. BMJ 2001;323:131-4

19 Vandenbroucke JP, Rosing J, Bloemenkamp KW, Middeldorp S, Helmerhorst FM, Bouma $\mathrm{BN}$, et al. Oral contraceptives and the risk of venous thrombosis. N Engl J Med 2001;344:1527-35

20 Jick SS, Hernandez RK. Risk of non-fatal venous thromboembolism in women using oral contraceptives containing drospirenone compared with women using oral contraceptives containing levonorgestrel: case-control study using United States claims data. BMJ 2011;342:d2151.

21 Parkin L, Sharples K, Hernandez RK, Jick SS. Risk of venous thromboembolism in users of oral contraceptives containing drospirenone or levonorgestrel: nested case-control study based on UK General Practice Research Database. BMJ 2011;342:d2139.

22 Nischan P, Ebeling K, Thomas DB, Hirsch U. Comparison of recalled and validated oral contraceptive histories. Am J Epidemiol 1993;138:697-703.

23 Norell SE, Boethius G, Persson I. Oral contraceptive use: interview data versus pharmacy records. Int J Epidemiol 1998;27:1033-7.

24 Wells PS, Hirsh J, Anderson DR, Lensing AW, Foster G, Kearon C, et al. Accuracy of clinical assessment of deep-vein thrombosis. Lancet 1995;345:1326-30.
25 Goodacre S, Sampson F, Stevenson M, Wailoo A, Sutton A, Thomas S, et al. Measurement of the clinical and cost-effectiveness of non-invasive diagnostic testing strategies for deep vein thrombosis. Health Technol Assess 2006;10:1-168.

26 Qaseem A, Snow V, Barry P, Hornbake ER, Rodnick JE, Tobolic T, et al. Current diagnosis of venous thromboembolism in primary care: a clinical practice guideline from the American Academy of Family Physicians and the American College of Physicians. Ann Fam Med 2007:5:57-62.

27 Grimes DA, Schulz KF. Compared to what? Finding controls for case-control studies. Lancet 2005;365:1429-33.

28 Raps M, Helmerhorst F, Fleischer K, Thomassen S, Rosendaal F, Rosing J, et al. Sex hormone-binding globulin as a marker for the thrombotic risk of hormonal contraceptives. $J$ Thromb Haemost 2012;10:992-7.

29 van Vliet HA, Frolich M, Christella M, Thomassen LG, Doggen CJ, Rosendaal FR, et al. Association between sex hormone-binding globulin levels and activated protein $\mathrm{C}$ resistance in explaining the risk of thrombosis in users of oral contraceptives containing different progestogens. Hum Reprod 2005;20:563-8.

30 White IR, Barrett JK, Jackson D, Higgins JPT. Consistency and inconsistency in network meta-analysis: model estimation using multivariate meta-regression. Research Synthesis Methods 2012;3:111-25.

31 Bird ST, Delaney JA, Etminan M, Brophy JM, Hartzema AG. Drospirenone and non-fatal venous thromboembolism: is there a risk difference by dosage of ethinyl-estradiol? J Thromb Haemost 2013;11:1059-68.

32 Gronich N, Lavi I, Rennert G. Higher risk of venous thrombosis associated with drospirenone-containing oral contraceptives: a population-based cohort study. CMAJ 2011;183:E1319-25.

33 Lidegaard O, Nielsen LH, Skovlund CW, Skjeldestad FE, Lokkegaard E. Risk of venous thromboembolism from use of oral contraceptives containing different progestogens and oestrogen doses: Danish cohort study, 2001-9. BMJ 2011;343:d6423.

34 Heinemann LA, Dinger JC, Assmann A, Minh TD. Use of oral contraceptives containing gestodene and risk of venous thromboembolism: outlook 10 years after the third-generation "pill scare". Contraception 2010;81:401-7.

35 Jick SS, Kaye JA, Russmann S, Jick H. Risk of nonfatal venous thromboembolism with oral contraceptives containing norgestimate or desogestrel compared with oral contraceptives containing levonorgestrel. Contraception 2006;73:566-70.

36 Samuelsson E, Hagg S. Incidence of venous thromboembolism in young Swedish women and possibly preventable cases among combined oral contraceptive users. Acta Obstet Gynecol Scand 2004;83:674-81.

37 Hedenmalm K, Samuelsson E, Spigset O. Pulmonary embolism associated with combined oral contraceptives: reporting incidences and potential risk factors for a fatal outcome. Acta Obstet Gynecol Scand 2004;83:576-85.

38 Heinemann LA, Lewis MA, Assmann A, Thiel C. Case-control studies on venous thromboembolism: bias due to design? A methodological study on venous thromboembolism and steroid hormone use. Contraception 2002;65:207-14

39 Lidegaard O, Edstrom B, Kreiner S. Oral contraceptives and venous thromboembolism: a five-year national case-control study. Contraception 2002;65:187-96.

40 Parkin L, Skegg DC, Wilson M, Herbison GP, Paul C. Oral contraceptives and fatal pulmonary embolism. Lancet 2000;355:2133-4.

41 Farmer RD, Lawrenson RA, Todd JC, Williams TJ, MacRae KD, Tyrer F, et al. A comparison of the risks of venous thromboembolic disease in association with different combined oral contraceptives. Br J Clin Pharmacol 2000;49:580-90.

42 Herings RM, Urquhart J, Leufkens HG. Venous thromboembolism among new users of different oral contraceptives. Lancet 1999;354:127-8.

43 Todd J, Lawrenson R, Farmer RD, Williams TJ, Leydon GM. Venous thromboembolic disease and combined oral contraceptives: a re-analysis of the MediPlus database. Hum Reprod 1999;14:1500-5.

44 Martinelli I, Taioli E, Bucciarelli P, Akhavan S, Mannucci PM. Interaction between the G20210A mutation of the prothrombin gene and oral contraceptive use in deep vein thrombosis. Arterioscler Thromb Vasc Biol 1999;19:700-3.

45 Bloemenkamp KW, Rosendaal FR, Buller HR, Helmerhorst FM, Colly LP, Vandenbroucke JP. Risk of venous thrombosis with use of current low-dose oral contraceptives is not explained by diagnostic suspicion and referral bias. Arch Intern Med 1999;159:65-70.

46 Farmer RD, Todd JC, Lewis MA, MacRae KD, Williams TJ. The risks of venous thromboembolic disease among German women using oral contraceptives: a database study. Contraception 1998;57:67-70.

47 Andersen BS, Olsen J, Nielsen GL, Steffensen FH, Sorensen HT, Baech J, et al. Third generation oral contraceptives and heritable thrombophilia as risk factors of non-fatal venous thromboembolism. Thromb Haemost 1998;79:28-31.

48 Lewis MA, Heinemann LA, MacRae KD, Bruppacher R, Spitzer WO. The increased risk of venous thromboembolism and the use of third generation progestagens: role of bias in observational research. The Transnational Research Group on Oral Contraceptives and the Health of Young Women. Contraception 1996;54:5-13.

49 Farmer R. Safety of modern oral contraceptives. Lancet 1996;347:259.

50 Bloemenkamp KW, Rosendaal FR, Helmerhorst FM, Buller HR, Vandenbroucke JP. Enhancement by factor $\mathrm{V}$ Leiden mutation of risk of deep-vein thrombosis associated with oral contraceptives containing a third-generation progestagen. Lancet 1995;346:1593-6.

51 Effect of different progestagens in low oestrogen oral contraceptives on venous thromboembolic disease. World Health Organization Collaborative Study of Cardiovascular Disease and Steroid Hormone Contraception. Lancet 1995;346:1582-8.

52 Vandenbroucke JP, Helmerhorst FM, Bloemenkamp KW, Rosendaal FR. Third-generation oral contraceptive and deep venous thrombosis: from epidemiologic controversy to new insight in coagulation. Am J Obstet Gynecol 1997:177:887-91.

53 Manzoli L, De Vito C, Marzuillo C, Boccia A, Villari P. Oral contraceptives and venous thromboembolism: a systematic review and meta-analysis. Drug Saf 2012;35:191-205.

54 Kemmeren JM, Algra A, Meijers JC, Bouma BN, Grobbee DE. Effects of second and third generation oral contraceptives and their respective progestagens on the coagulation system in the absence or presence of the factor V Leiden mutation. Thromb Haemost 2002;87:199-205.

55 Kemmeren JM, Algra A, Meijers JC, Tans G, Bouma BN, Curvers J, et al. Effect of secondand third-generation oral contraceptives on the protein $C$ system in the absence or presence of the factor VLeiden mutation: a randomized trial. Blood 2004;103:927-33.

56 van Hylckama Vlieg, A, Helmerhorst FM, Rosendaal FR. The risk of deep venous thrombosis associated with injectable depot-medroxyprogesterone acetate contraceptives or a levonorgestrel intrauterine device. Arterioscler Thromb Vasc Biol 2010;30:2297-300. 


\section{What is already known on this topic}

Combined oral contraceptive use increases the risk of venous thrombosis

Despite the low incidence of venous thrombosis, the risk in women using combined oral contraceptives is a real concern because of the widespread use of these contraceptives

\section{What this paper adds}

Risk of venous thrombosis for combined oral contraceptives with $30-35 \mu \mathrm{g}$ ethinylestradiol and gestodene, desogestrel, cyproterone acetate and drospirenone were similar, and about $50-80 \%$ higher than with levonorgestrel

The combined oral contraceptive with the lowest possible dose of ethinylestradiol and good compliance should be prescribed-that is, $30 \mu \mathrm{g}$ ethinylestradiol with levonorgestrel estrogen combined oral contraceptives for contraception. Cochrane Database Syst Rev 2008;8:CD003989

Accepted: 12 August 2013

\section{Cite this as: BMJ 2013;347:f5298}

This is an Open Access article distributed in accordance with the Creative Commons Attribution Non Commercial (CC BY-NC 3.0) license, which permits others to distribute, remix, adapt, build upon this work non-commercially, and license their derivative works on different terms, provided the original work is properly cited and the use is

non-commercial. See: http://creativecommons.org/licenses/by-nc/3.0/. 


\section{Tables}

\begin{tabular}{|c|c|c|c|c|c|c|c|c|c|}
\hline \multicolumn{10}{|c|}{ Table 1/ Characteristics of included studies } \\
\hline Author (year) & Start date & End date & $\begin{array}{l}\text { Study } \\
\text { design }\end{array}$ & Setting & $\begin{array}{l}\text { Venous } \\
\text { thrombosis } \\
\text { diagnosis }\end{array}$ & $\begin{array}{l}\text { Age range } \\
\text { (years) }\end{array}$ & $\begin{array}{c}\text { No of } \\
\text { participants }\end{array}$ & $\begin{array}{l}\text { Adjustment } \\
\quad \text { for } \\
\text { confounding }\end{array}$ & Country \\
\hline Bird $^{31}(2013)$ & 1 May 2001 & 31 Dec 2009 & Cohort & $\begin{array}{l}\text { Healthcare } \\
\text { plan }\end{array}$ & Anticoagulation & $18-46$ & $\begin{array}{c}432178 \text { women } \\
(263902 \text { WY })\end{array}$ & Yes & USA \\
\hline Gronich $^{32}$ (2011) & 1 Jan 2002 & $31 \mathrm{Dec} 2008$ & Cohort & $\begin{array}{l}\text { Healthcare } \\
\text { plan }\end{array}$ & Ad hoc & $12-50$ & $\begin{array}{c}329995 \text { women } \\
\text { (819 } 749 \text { WY) }\end{array}$ & Yes & Israel \\
\hline Lidegaard $^{33}$ (2011) & 1 Jan 2001 & 31 Dec 2009 & Cohort & $\begin{array}{l}\text { Community } \\
\text { based }\end{array}$ & Anticoagulation & $15-49$ & $\begin{array}{l}1436310 \text { women } \\
\text { (9 } 954925 \text { WY) }\end{array}$ & Yes & Denmark \\
\hline $\operatorname{Jick}^{20}(2011)$ & 1 Jan 2002 & 31 Dec 2008 & $\begin{array}{c}\text { Nested } \\
\text { case-control }\end{array}$ & $\begin{array}{c}\text { Claims } \\
\text { database }\end{array}$ & Anticoagulation & $15-44$ & $\begin{array}{l}186 \text { cases; } 681 \\
\text { controls }\end{array}$ & $\begin{array}{c}\text { Yes } \\
\text { (matched) }\end{array}$ & USA \\
\hline Parkin ${ }^{21}$ (2011) & 1 May 2002 & 30 Sep 2009 & $\begin{array}{c}\text { Nested } \\
\text { case-control }\end{array}$ & GP database & Anticoagulation & $15-44$ & $\begin{array}{c}61 \text { cases; } 215 \\
\text { controls }\end{array}$ & $\begin{array}{c}\text { Yes } \\
\text { (matched) }\end{array}$ & UK \\
\hline Heinemann $^{34}(2010)$ & Jan 2002 & Feb 2006 & Case-control & $\begin{array}{c}\text { Community } \\
\text { based }\end{array}$ & Clinical criteria & $15-49$ & $\begin{array}{l}451 \text { cases; } 1920 \\
\text { controls }\end{array}$ & Yes & Austria \\
\hline $\begin{array}{l}\text { van Hylckama } \\
\text { Vlieg }^{17}(2009)\end{array}$ & Mar 1999 & Sep 2004 & Case-control & $\begin{array}{c}\text { Community } \\
\text { based }\end{array}$ & Anticoagulation & $<50$ & $\begin{array}{c}1524 \text { cases; } 1760 \\
\text { controls }\end{array}$ & Yes & Netherlands \\
\hline $\operatorname{Jick}^{35}(2006)$ & Jan 2000 & Mar 2005 & $\begin{array}{c}\text { Nested } \\
\text { case-control }\end{array}$ & $\begin{array}{c}\text { Claims } \\
\text { database }\end{array}$ & Anticoagulation & $15-39$ & $\begin{array}{l}281 \text { cases; } 1055 \\
\text { controls }\end{array}$ & $\begin{array}{c}\text { Yes } \\
\text { (matched) }\end{array}$ & USA \\
\hline $\begin{array}{l}\text { Samuelsson }{ }^{36} \\
(2004)\end{array}$ & 1 Jan 1991 & $31 \mathrm{Dec} 2000$ & Cohort & $\begin{array}{c}\text { Adverse events } \\
\text { database }\end{array}$ & Anticoagulation & $15-44$ & $\begin{array}{c}88 \text { cases ( } 243723 \\
\text { WY) }\end{array}$ & No & Sweden \\
\hline $\begin{array}{l}\text { Hedenmalm }{ }^{37} \\
(2004)\end{array}$ & 1965 & 2001 & Cohort & $\begin{array}{c}\text { Community } \\
\text { based }\end{array}$ & Medical records & - & $\begin{array}{c}172 \text { cases (10 } 016 \\
194 \mathrm{TY})\end{array}$ & No & Sweden \\
\hline Heinemann ${ }^{38}(2002)$ & Jan 1994 & Jul 1999 & Case-control & $\begin{array}{c}\text { Community } \\
\text { based }\end{array}$ & Clinical criteria & $15-49$ & $\begin{array}{c}606 \text { cases; } 2942 \\
\text { controls }\end{array}$ & Yes & Germany \\
\hline Lidegaard $^{39}(2002)$ & 1 Jan 1994 & 30 Dec 1998 & Case-control & $\begin{array}{c}\text { Community } \\
\text { based }\end{array}$ & Discharges & $15-44$ & $\begin{array}{c}987 \text { cases; } 4054 \\
\text { controls }\end{array}$ & $\begin{array}{c}\text { Yes } \\
\text { (matched) }\end{array}$ & Denmark \\
\hline Parkin $^{40}(2000)$ & Jan 1990 & Aug 1998 & Case-control & GP database & $\begin{array}{l}\text { Death } \\
\text { certificate }\end{array}$ & $\begin{array}{c}\text { Not } \\
\text { postmenopausal }\end{array}$ & $\begin{array}{l}26 \text { cases; } 111 \\
\text { controls }\end{array}$ & Yes & $\begin{array}{l}\text { New } \\
\text { Zealand }\end{array}$ \\
\hline Farmer $^{41}(2000)$ & Jan 1992 & Jun 1997 & Cohort & $\begin{array}{c}\text { Prescription } \\
\text { database }\end{array}$ & Ad hoc & $15-49$ & $\begin{array}{c}287 \text { cases (783 } \\
876 \text { WY) }\end{array}$ & No & UK \\
\hline Herings $^{42}$ (1999) & 1986 & 1995 & Cohort & $\begin{array}{l}\text { Prescription } \\
\text { database }\end{array}$ & Ad hoc & $15-49$ & $\begin{array}{c}33 \text { cases; } 450000 \\
\text { women }\end{array}$ & Yes & Netherlands \\
\hline $\operatorname{Todd}^{43}$ (1999) & 1992 & Mar 1997 & Cohort & $\begin{array}{l}\text { Healthcare } \\
\text { plan }\end{array}$ & Anticoagulation & $15-49$ & $\begin{array}{c}99 \text { cases (216 } 356 \\
\text { WY) }\end{array}$ & No & UK \\
\hline Martinelliti (1999) & Apr 1995 & Apr 1998 & Case-control & $\begin{array}{c}\text { Community } \\
\text { based }\end{array}$ & Ad hoc & - & Unclear* & No & Italy \\
\hline $\begin{array}{l}\text { Bloemenkamp }{ }^{45} \\
\text { (1999) }\end{array}$ & 1 Sep 1982 & 18 Oct 1995 & Case-control & $\begin{array}{c}\text { Community } \\
\text { based }\end{array}$ & $\begin{array}{l}\text { Imaging } \\
\text { techniques }\end{array}$ & $15-49$ & $\begin{array}{c}185 \text { cases; } 591 \\
\text { controls }\end{array}$ & Yes & Netherlands \\
\hline Farmer $^{46}(1998)$ & Oct 1992 & Sep 1995 & Case-control & $\begin{array}{l}\text { Healthcare } \\
\text { plan }\end{array}$ & Anticoagulation & $18-49$ & $\begin{array}{l}42 \text { cases; } 168 \\
\text { controls }\end{array}$ & $\begin{array}{c}\text { Yes } \\
\text { (matched) }\end{array}$ & Germany \\
\hline Andersen $^{47}(1998)$ & - & - & Case-control & $\begin{array}{c}\text { Hospital } \\
\text { discharge }\end{array}$ & Anticoagulation & - & $\begin{array}{c}67 \text { cases; } 134 \\
\text { controls }\end{array}$ & $\begin{array}{c}\text { Yes } \\
\text { (matched) }\end{array}$ & Denmark \\
\hline Lewis $^{48}(1996)$ & Jul 1991 & Dec 1995 & Case-control & $\begin{array}{c}\text { Community } \\
\text { based }\end{array}$ & $\begin{array}{c}\text { Clinical } \\
\text { symptoms }\end{array}$ & $16-45$ & $\begin{array}{c}505 \text { cases; } 1877 \\
\text { controls }\end{array}$ & $\begin{array}{c}\text { Yes } \\
\text { (matched) }\end{array}$ & $\begin{array}{l}\text { UK and } \\
\text { Germany }\end{array}$ \\
\hline Farmer $^{49}(1996)$ & - & - & Cohort & GP database & Anticoagulation & $14-45$ & $\begin{array}{c}30 \text { cases; } 697000 \\
\text { women }\end{array}$ & Yes & UK \\
\hline $\begin{array}{l}\text { Bloemenkamp }{ }^{50} \\
\text { (1995) }\end{array}$ & 1 Jan 1988 & 31 Dec 1995 & Case-control & $\begin{array}{c}\text { Community } \\
\text { based }\end{array}$ & Anticoagulation & $15-49$ & $\begin{array}{c}126 \text { cases; } 159 \\
\text { controls }\end{array}$ & Yes & Netherlands \\
\hline $\mathrm{WHO}^{51}$ (1995) & 1 Feb 1989 & 31 Jan 1993 & Case-control & $\begin{array}{c}\text { Community } \\
\text { based }\end{array}$ & Clinical criteria & - & $\begin{array}{l}829 \text { cases; } 1979 \\
\text { controls }\end{array}$ & $\begin{array}{c}\text { Yes } \\
\text { (matched) }\end{array}$ & 9 countries $\dagger$ \\
\hline WHO $1^{10}(1995)$ & 1 Feb 1989 & 3 Jan 1993 & Case-control & $\begin{array}{c}\text { Community } \\
\text { based }\end{array}$ & Clinical criteria & $20-44$ & $\begin{array}{c}433 \text { cases; } 1044 \\
\text { controls }\end{array}$ & Yes & Europe \\
\hline WHO $2^{10}$ (1995) & 1 Feb 1989 & 3 Jan 1993 & Case-control & $\begin{array}{l}\text { Community } \\
\text { based }\end{array}$ & Clinical criteria & $20-44$ & $\begin{array}{l}710 \text { cases; } 1954 \\
\text { controls }\end{array}$ & Yes & $\begin{array}{c}\text { Developing } \\
\text { countries }\end{array}$ \\
\hline
\end{tabular}


Table 1 (continued)

\begin{tabular}{|c|c|c|c|c|c|c|c|c|c|}
\hline Author (year) & Start date & End date & $\begin{array}{c}\text { Study } \\
\text { design }\end{array}$ & Setting & $\begin{array}{l}\text { Venous } \\
\text { thrombosis } \\
\text { diagnosis }\end{array}$ & $\begin{array}{l}\text { Age range } \\
\text { (years) }\end{array}$ & $\begin{array}{c}\text { No of } \\
\text { participants }\end{array}$ & $\begin{array}{l}\text { Adjustment } \\
\text { for } \\
\text { confounding }\end{array}$ & Country \\
\hline
\end{tabular}


Table 2| Network meta-analysis, by generation of progestogen used in combined oral contraceptives

\begin{tabular}{lcccc} 
& & \multicolumn{4}{c}{ Generation of progestogen } \\
\cline { 2 - 5 } & Non-use & First & Second & Third \\
Non-use & 1 & - & - & - \\
\hline First generation & $3.2(2.0$ to 5.1$)$ & 1 & - & - \\
\hline Second generation & $2.8(2.0$ to 4.1$)$ & $0.9(0.6$ to 1.4$)$ & 1 & \\
\hline Third generation & $3.8(2.7$ to 5.4$)$ & $1.2(0.8$ to 1.9$)$ & $1.3(1.0$ to 1.8$)$ & 1 \\
\hline
\end{tabular}

Data are relative risk ( $95 \%$ confidence interval) of venous thrombosis. 


\begin{tabular}{|c|c|c|c|c|c|c|c|c|c|c|c|}
\hline & $\begin{array}{c}\text { Non-use } \\
\text { (reference } \\
\text { group) }\end{array}$ & 20LNG & 30LNG & 50LNG & 20GSD & 30GSD & 20DSG & 30DSG & 35NRG & 35CPA & 30DRSP \\
\hline Non-use & 1 & - & - & - & - & - & - & - & - & - & - \\
\hline 20LNG & $\begin{array}{c}2.2(1.3 \text { to } \\
3.6)\end{array}$ & 1 & $\begin{array}{c}0.9 \text { (0.6 to } \\
1.4)\end{array}$ & $\begin{array}{c}0.4(0.2 \text { to } \\
0.8)\end{array}$ & $\begin{array}{c}1.0(0.6 \\
(1.8)\end{array}$ & $\begin{array}{c}0.6(0.4 \text { to } \\
1.0)\end{array}$ & $\begin{array}{c}0.7(0.4 \text { to } \\
1.1)\end{array}$ & $\begin{array}{c}0.5 \text { (0.3 to } \\
0.8)\end{array}$ & $\begin{array}{c}0.9 \text { (0.5 to } \\
1.5)\end{array}$ & $\begin{array}{c}0.6(0.3 \text { to } \\
1.0)\end{array}$ & $\begin{array}{c}0.6(0.4 \text { to } \\
0.9)\end{array}$ \\
\hline 30LNG & $\begin{array}{c}2.4(1.8 \text { to } \\
3.2)\end{array}$ & $\begin{array}{c}1.1 \text { ( } 0.7 \text { to } \\
1.7)\end{array}$ & 1 & $\begin{array}{c}0.5(0.3 \text { to } \\
0.7)\end{array}$ & $\begin{array}{c}1.1 \text { ( } 0.8 \text { to } \\
1.7)\end{array}$ & $\begin{array}{c}0.7 \text { ( } 0.5 \text { to } \\
0.9)\end{array}$ & $\begin{array}{c}0.7 \text { ( } 0.5 \text { to } \\
1.0)\end{array}$ & $\begin{array}{c}0.6 \text { (0.4 to } \\
0.7)\end{array}$ & $\begin{array}{c}1.0(0.7 \text { to } \\
1.4)\end{array}$ & $\begin{array}{c}0.6(0.4 \text { to } \\
0.9)\end{array}$ & $\begin{array}{c}0.6(0.5 \text { to } \\
0.8)\end{array}$ \\
\hline 50LNG & $\begin{array}{c}5.2 \text { (3.4 to } \\
7.9)\end{array}$ & $\begin{array}{c}2.3(1.3 \text { to } \\
4.2)\end{array}$ & $\begin{array}{c}2.1 \text { (1.4 to } \\
3.2)\end{array}$ & 1 & $\begin{array}{c}2.4(1.5 \text { to } \\
4.0)\end{array}$ & $\begin{array}{c}1.4(0.9 \text { to } \\
2.1)\end{array}$ & $\begin{array}{c}1.5 \text { (1.0 to } \\
2.4)\end{array}$ & $\begin{array}{c}1.2(0.8 \text { to } \\
1.8)\end{array}$ & $\begin{array}{c}2.2 \text { (1.4 to } \\
3.3)\end{array}$ & $\begin{array}{c}1.3(0.8 \text { to } \\
2.1)\end{array}$ & $\begin{array}{c}1.3(0.8 \text { to } \\
2.1)\end{array}$ \\
\hline 20GSD & $\begin{array}{c}2.2(1.4 \text { to } \\
3.2)\end{array}$ & $\begin{array}{c}1.0(0.5 \text { to } \\
1.7)\end{array}$ & $\begin{array}{c}0.9 \text { (0.6 to } \\
1.3)\end{array}$ & $\begin{array}{c}0.4(0.3 \text { to } \\
0.7)\end{array}$ & 1 & $\begin{array}{c}0.6(0.4 \text { to } \\
0.9)\end{array}$ & $\begin{array}{c}0.6(0.4 \text { to } \\
1.0)\end{array}$ & $\begin{array}{c}0.5 \text { (0.3 to } \\
0.7)\end{array}$ & $\begin{array}{c}0.9 \text { (0.6 to } \\
1.4)\end{array}$ & $\begin{array}{c}0.6(0.4 \text { to } \\
0.8)\end{array}$ & $\begin{array}{c}0.6(0.4 \text { to } \\
0.9)\end{array}$ \\
\hline 30GSD & $\begin{array}{c}3.7 \text { (2.8 to } \\
4.9)\end{array}$ & $\begin{array}{c}1.7 \text { (1.0 to } \\
2.7)\end{array}$ & $\begin{array}{c}1.5 \text { (1.2 to } \\
2.0)\end{array}$ & $\begin{array}{c}0.7(0.5 \text { to } \\
1.1)\end{array}$ & $\begin{array}{c}1.7(1.1 \text { to } \\
2.6)\end{array}$ & 1 & $\begin{array}{c}1.1 \text { (0.8 to } \\
1.5)\end{array}$ & $\begin{array}{c}0.9(0.7 \text { to } \\
1.1)\end{array}$ & $\begin{array}{c}1.5 \text { (1.1 to } \\
2.1)\end{array}$ & $\begin{array}{c}1.0(0.7 \text { to } \\
1.4)\end{array}$ & $\begin{array}{c}1.0(0.7 \text { to } \\
1.3)\end{array}$ \\
\hline 20DSG & $\begin{array}{c}3.4(2.5 \text { to } \\
4.6)\end{array}$ & $\begin{array}{c}1.5(0.9 \text { to } \\
2.6)\end{array}$ & $\begin{array}{c}1.4(1.0 \text { to } \\
1.9)\end{array}$ & $\begin{array}{c}0.7(0.4 \text { to } \\
1.0)\end{array}$ & $\begin{array}{c}1.6(1.0 \text { to } \\
2.4)\end{array}$ & $\begin{array}{c}0.9(0.7 \text { to } \\
1.2)\end{array}$ & 1 & $\begin{array}{c}0.8 \text { (0.6 to } \\
1.1)\end{array}$ & $\begin{array}{c}1.4(1.0 \text { to } \\
2.0)\end{array}$ & $\begin{array}{c}0.9(0.6 \text { to } \\
1.3)\end{array}$ & $\begin{array}{c}0.9 \text { (0.6 to } \\
1.3)\end{array}$ \\
\hline 30DSG & $\begin{array}{c}4.3(3.3 \text { to } \\
5.6)\end{array}$ & $\begin{array}{c}1.9(1.2 \text { to } \\
3.1)\end{array}$ & $\begin{array}{c}1.8(1.4 \text { to } \\
2.2)\end{array}$ & $\begin{array}{c}0.8(0.5 \text { to } \\
1.2)\end{array}$ & $\begin{array}{c}2.0(1.3 \text { to } \\
2.9)\end{array}$ & $\begin{array}{c}1.2(0.9 \text { to } \\
1.5)\end{array}$ & $\begin{array}{c}1.3(0.9 \text { to } \\
1.7)\end{array}$ & 1 & $\begin{array}{c}1.8(1.3 \text { to } \\
2.4)\end{array}$ & $\begin{array}{c}1.1(0.8 \text { to } \\
1.6)\end{array}$ & $\begin{array}{c}1.1(0.8 \text { to } \\
1.5)\end{array}$ \\
\hline $35 N R G$ & $\begin{array}{c}2.4(1.7 \text { to } \\
3.3)\end{array}$ & $\begin{array}{c}1.1(0.7 \text { to } \\
1.8)\end{array}$ & $\begin{array}{c}1.0(0.7 \text { to } \\
1.3)\end{array}$ & $\begin{array}{c}0.5 \text { (0.3 to } \\
0.7)\end{array}$ & $\begin{array}{c}1.1(0.7 \text { to } \\
1.7)\end{array}$ & $\begin{array}{c}0.7 \text { (0.5 to } \\
0.9)\end{array}$ & $\begin{array}{c}0.7 \text { (0.5 to } \\
1.0)\end{array}$ & $\begin{array}{c}0.6(0.4 \text { to } \\
0.8)\end{array}$ & 1 & $\begin{array}{c}0.6(0.4 \text { to } \\
0.9)\end{array}$ & $\begin{array}{c}0.6(0.4 \text { to } \\
0.9)\end{array}$ \\
\hline $35 \mathrm{CPA}$ & $\begin{array}{c}3.9(2.7 \text { to } \\
5.5)\end{array}$ & $\begin{array}{c}1.7 \text { (1.0 to } \\
3.0)\end{array}$ & $\begin{array}{c}1.6(1.1 \text { to } \\
2.2)\end{array}$ & $\begin{array}{c}0.7(0.5 \text { to } \\
1.2)\end{array}$ & $\begin{array}{c}1.8(1.1 \text { to } \\
2.8)\end{array}$ & $\begin{array}{c}1.0(0.7 \text { to } \\
1.5)\end{array}$ & $\begin{array}{c}1.1(0.8 \text { to } \\
1.6)\end{array}$ & $\begin{array}{c}0.9(0.6 \text { to } \\
1.3)\end{array}$ & $\begin{array}{c}1.6(1.1 \text { to } \\
2.3)\end{array}$ & 1 & $\begin{array}{c}1.0(0.7 \text { to } \\
1.5)\end{array}$ \\
\hline 30DRSP & $\begin{array}{c}3.9(2.7 \text { to } \\
5.5)\end{array}$ & $\begin{array}{c}1.7(1.1 \text { to } \\
2.7)\end{array}$ & $\begin{array}{c}1.6(1.2 \text { to } \\
2.1)\end{array}$ & $\begin{array}{c}0.7(0.5 \text { to } \\
1.2)\end{array}$ & $\begin{array}{c}1.8(1.2 \text { to } \\
2.8)\end{array}$ & $\begin{array}{c}1.1 \text { (0.7 to } \\
1.5)\end{array}$ & $\begin{array}{c}1.1(0.8 \text { to } \\
1.6)\end{array}$ & $\begin{array}{c}0.9 \text { (0.7 to } \\
1.3)\end{array}$ & $\begin{array}{c}1.6(1.1 \text { to } \\
2.3)\end{array}$ & $\begin{array}{c}1.0(0.7 \text { to } \\
1.5)\end{array}$ & 1 \\
\hline
\end{tabular}

Data are relative risk ( $95 \%$ confidence interval) of venous thrombosis. $20 \mathrm{LNG}=20 \mu \mathrm{g}$ ethinylestradiol with levonorgestrel; $30 \mathrm{LNG}=30 \mu \mathrm{g}$ ethinylestradiol with levonorgestrel; $50 \mathrm{LNG}=50 \mu \mathrm{g}$ ethinylestradiol with levonorgestrel; $20 \mathrm{GSD}=20 \mu \mathrm{g}$ ethinylestradiol with gestodene; $30 \mathrm{GSD}=30 \mu \mathrm{g}$ ethinylestradiol with gestodene; $20 \mathrm{DSG}=20 \mu \mathrm{g}$ ethinylestradiol with desogestrel; $30 \mathrm{DSG}=30 \mu \mathrm{g}$ ethinylestradiol with desogestrel; $35 \mathrm{NRG}=35 \mu \mathrm{g}$ ethinylestradiol with norgestimate; $35 \mathrm{CPA}=35 \mu \mathrm{g}$ ethinylestradiol with cyproterone acetate; $30 \mathrm{DRSP}=30 \mu \mathrm{g}$ ethinylestradiol with drospirenone. 
Table 4| Sensitivity analyses

\begin{tabular}{|c|c|c|c|c|c|c|}
\hline \multirow[b]{2}{*}{$\begin{array}{l}\text { Generation of } \\
\text { progestogen }\end{array}$} & \multicolumn{6}{|c|}{ Source of bias and No of studies } \\
\hline & Industry $(\mathrm{n}=8)$ & Non-industry $(n=9)$ & Cohort study $(n=8)$ & Case-control $(n=15)$ & $\begin{array}{l}\text { Objectively confirmed } \\
\text { venous thrombosis }(n=5)\end{array}$ & $\begin{array}{l}\text { Subjectively confirmed } \\
\text { venous thrombosis }(n=11)\end{array}$ \\
\hline Non-use & 1 & 1 & 1 & 1 & 1 & 1 \\
\hline First & $2.6(0.9$ to 7.4$)$ & 3.3 (2.4 to 4.6$)$ & $2.0(0.4$ to 10.5$)$ & $3.3(2.3$ to 4.7$)$ & 4.5 (3.2 to 6.5$)$ & $2.6(1.3$ to 5.3$)$ \\
\hline Second & $2.1(1.0$ to 4.8$)$ & 3.1 (2.5 to 3.8$)$ & $1.7(0.4$ to 8.0$)$ & 2.9 (2.3 to 3.7$)$ & $3.3(2.8$ to 4.0$)$ & 2.5 (1.4 to 4.5$)$ \\
\hline Third & $1.9(0.8$ to 4.2$)$ & $5.2(4.2$ to 6.5$)$ & $2.0(0.5$ to 8.6$)$ & 4.2 (3.3 to 5.3$)$ & $6.2(5.2$ to 7.4$)$ & $3.0(1.7$ to 5.4$)$ \\
\hline
\end{tabular}

Data are relative risk ( $95 \%$ confidence interval) of venous thrombosis. 


\section{Figures}

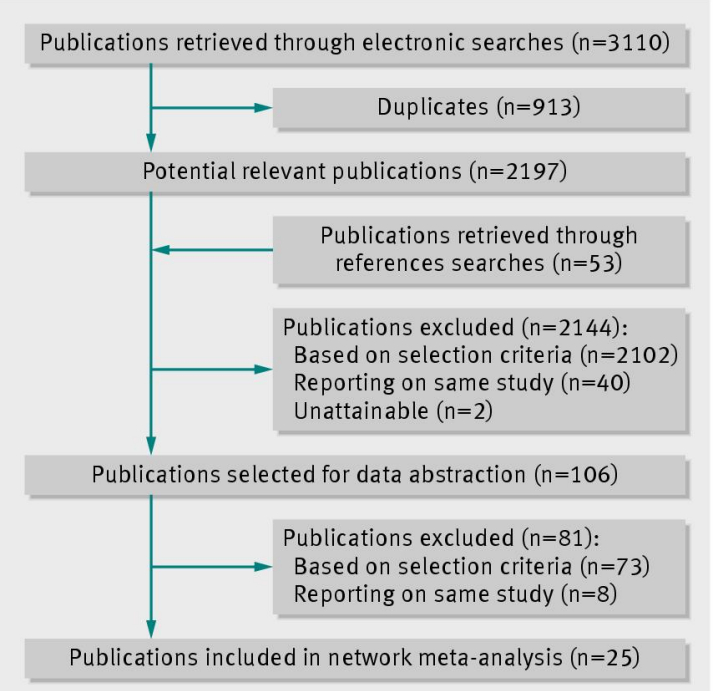

Fig 1 Flow diagram of included and excluded publications

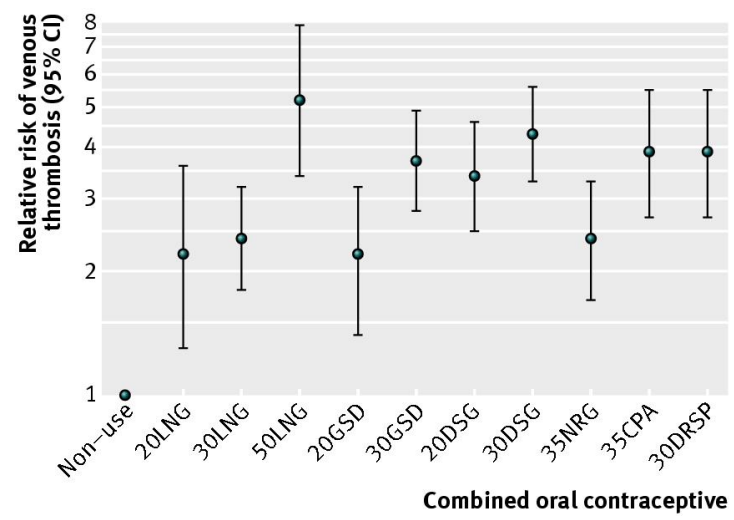

Fig 2 Network meta-analysis, per contraceptive plotted on a logarithmic scale. 20LNG=20 $\mu$ g ethinylestradiol with levonorgestrel; $30 \mathrm{LNG}=30 \mu \mathrm{g}$ ethinylestradiol with levonorgestrel; $50 \mathrm{LNG}=50 \mu \mathrm{g}$ ethinylestradiol with levonorgestrel; $20 \mathrm{GSD}=20 \mu \mathrm{g}$ ethinylestradiol with gestodene; $30 \mathrm{GSD}=30 \mu \mathrm{g}$ ethinylestradiol with gestodene; $20 \mathrm{DSG}=20 \mu \mathrm{g}$ ethinylestradiol with desogestrel; $30 \mathrm{DSG}=30 \mu \mathrm{g}$ ethinylestradiol with desogestrel; $35 \mathrm{NRG}=35 \mu \mathrm{g}$ ethinylestradiol with norgestimate; $35 \mathrm{CPA}=35 \mu \mathrm{g}$ ethinylestradiol with cyproterone acetate; 30DRSP $=30 \mu \mathrm{g}$ ethinylestradiol with drospirenone; dots (lines) =overall relative risk ( $95 \%$ confidence interval) of venous thrombosis; non-use=reference group 